\title{
Conclusion: Engineering Movies
}

Cinema has been constructed as being animated by different energies over its history, including spectral haunting, mechanization, and electricity. ${ }^{1}$ Nonlinear mathematics represents another addition to this list, one aligned with the archeological layer of the past few decades. While early special effects films like Segundo de Chomón's The Electric Hotel (1908) saw electricity brining household items to life so they could speed around the room with a mind of their own, now we see animating liveliness in things like random numbers or dynamic calculations. This form of vitality requires engineering computational apparatuses. This is a different kind of work that entails a different balance between animation and automation than that of manual animation or traditional live-action film recording.

The nonlinear simulation and animation technologies discussed in the preceding chapters took shape in a specific historical, institutional, economic, and political context. The Second World and Cold War R\&D complexes took decades-old concepts from mathematicians like Henri Poincaré and developed them into simulation technologies. The period that followed, which saw a shift from publicly sponsored R\&D to tax-incentivized private $\mathrm{R} \& \mathrm{D}$, further developed these technologies to specific media industry ends. As Raymond William's famous critique of technological determinism reminds us, $\mathrm{R} \& \mathrm{D}$ is a place where we can see society influencing the shape of new media technologies, even before they are put to use. ${ }^{2}$

(c) The Author(s) 2021

J. Gowanlock, Animating Unpredictable Effects, Palgrave Animation, https://doi.org/10.1007/978-3-030-74227-0_7 
Nonlinear animation was but one mode of production in film industries during this period, and it was a limited, often very compartmentalized, one at that. These new animation tools and practices developed in complex relation to other changes like the rise of $\mathrm{R} \& \mathrm{D}$ within film production, the emergence of self-styled Silicon-Valley-meets-Hollywood studios, a marked shift toward globalized post-production labor, and the rise of competitive bidding in the VFX industry. Nonlinear animation was shaped by these changes but also fed into them. Buoyed by the strategic and economic value of R\&D and the logic of blockbusters, it influenced not just the way movies were made but also the way studios sought to manage production labor.

Nonlinear animation offers greater control over contingency and materiality than camera and film. While the appearance of filmed smoke or water can certainly by altered, you cannot really tell it how to move. Nonlinear animation affords that kind of control. At the same time, it is more representationally restrictive than traditional animation, more reliant on a rationalizing, discretizing way of seeing the world. Nonlinear animation seems to suggest that film studios are thinking even more like managers, investors, and military scientists than ever before. Many uses of nonlinear animation are prime examples of hyperrealism, a term that has been applied to specific uses other animation techniques like the multiplane camera, Cartesian 3D, and ray-tracing rendering.

Hyperrealism means slightly different things to different scholars, with varying degrees of distance from Baudrillard's original postmodern meaning of the term. It can be a way for film theorists to identify new digital threats to cinematic realism. For example, Dudley Andrew roundly criticizes the film Amélie (2001) for its seamless digitally retouched, hyperrealistic appearance. ${ }^{3}$ Conversely, hyperrealism can also be used by animation and digital media scholars to identify forms of moving images that unreflexively use given forms of representation, rather than making use of the representational flexibility of animation. Here the terms "second-order realism" and photorealism are very close to hyperrealism. ${ }^{4}$

Contrary to the way a traditionalist film theorist might celebrate cinema's fidelity to reality, animations scholars tend to celebrate a total lack of representational fixedness. Animation's capacity for formless fluidity could perhaps be called the central principle of animation studies. The oft-cited ur-theory of this discourse is Sergei Eisenstein's description of the "plasmatic" nature of early Disney shorts. Though Eisenstein sees animated plasmaticness as an escapist symptom of capitalism, he cannot help but 
appreciate the anarchic potential of the formless transformation of Disney characters. ${ }^{5}$ Much contemporary theory follows in this logic. Paul Wells uses Felix the Cat cartoons as an example of how animation's capacity to present a topsy-turvy anarchic world has subversive potential. ${ }^{6}$ Similarly, Norman Klein celebrates animation's ability to create "ani-morphs," images that are suspended in an in-between state of a process of transformation. ${ }^{7}$ The animation studies canon is full of examples of this kind of formlessness, from Émile Cohl's Phantasmagoria (1908) to Ryan Larkin's Walking (1969). This way of thinking about animation situates it as a place to question and destabilize the rigid representational form of photographic cinema. A good example of this is animated documentary, which tends to question the authority of objectivity in favor of different, often subjective or experiential, epistemologies. In examples like Waltz with Bashir (2008), animators convey the affective quality of the experience of memory and dreams, rather than objective truth.

These commitments dictate the use of the term hyperrealism for animation scholars as a kind of antithesis. For example, Wells uses the term to describe the look of Disney's animated features. The films that follow in the tradition of Bambi (1942) and Snow White (1937), which use techniques like the multiplane camera, generally try to mimic the perspective and appearance of photographic film. The characters do not squash or stretch, or defy physics, they exist in a stable world of rules that mimic our settled ways of seeing. ${ }^{8}$ For Wells this is a betrayal of the immense potential of animation.

As animation theorists struggled to make sense of the numerical and logical nature of digital animation, hyperrealism proved a useful point of distinction. While Pat Power acknowledges that digital animation's origin in the military-industrial complex and Cartesian single-point perspective cause it to mostly take the shape of hyperrealism, he defends digital animation because individual artists can use these tools for expressive ends. ${ }^{9}$ Digital animation can escape hyperrealism when it appeals to the realm of "emotion, memory and imagination," when it portrays subjective realism rather than objective realism. ${ }^{10}$ To Power this is an appropriation, or detournement, of the objective, rationalizing DNA of digital tools.

Some of these critiques sound like they are merely enforcing prescriptive definitions of different media modes: "animation should be this and live-action cinema should be this and never the two shall meet." There is certainly an element of this thinking in Andrew's work. Yet animation scholars have tended to embrace the uncertain borders of the form, 
celebrating experimental work by artist like Norman McLaren or Stan Brakhage that does not fit readily into either category. Animation is, of course, a big category that includes a diversity of moving images, including the "super genre" of live-action. And as Karen Redrobe argues in her edited collection on the topic, thinking through binaries like "continuous versus non-continuous, narrative versus experimental, indexical versus handmade, and animated versus live action" leads to innumerable blind spots. ${ }^{11}$

Instead, the use of the term hyperrealism by animation scholars identifies a form of representation that is restrictive, un-reflexive, and borrowed from somewhere else. These forms of representation can carry ideological baggage along with them through the entanglement of power and knowledge. Cartesian perspective, for example, was famously critiqued by scholars like Jean-Louis Baudry. ${ }^{12}$ Forms like nonlinear animation and simulated physics borrow from science and the military, sources where the relationship between power and knowledge is especially tight.

This is a critique Lev Manovich makes of certain simulation-based forms of digital animation. In The Language of New Media Manovich puts physical simulation into a category of hyperrealism, alongside other second-order realist computer graphics techniques like sophisticated lighting and lens effects. ${ }^{13} \mathrm{He}$ notes the involvement of SIGGRAPH as a reason realism has become such an important concern in computer graphics (when he was writing in 2001). Manovich bases his critique on a precedent set by David Bordwell and Janet Staiger's work on the form of classic Hollywood Cinema. They argue that the society for motion picture and television engineers (SMPTE) "rationally adopted" realism "as an engineering aim."14 Manovich finds that the US Military and Hollywood have done much the same at SIGGRAPH. The former wanted realism for immersive simulators, and the later wanted it for VFX and animation. He writes,

What determined which particular problems received priority in research? To a large extent, this was determined by the needs of the early sponsors of this research - the Pentagon and Hollywood .... The requirements of military and entertainment applications led researchers to concentrate on the simulation of the particular phenomena of visual reality, such as landscapes and moving figures. ${ }^{15}$ 
Both the military and Hollywood's R\&D complexes were seeking a cold, fixed, instrumentalized, realism, the vision of industry and military, rather than artistry. To be clear, this is not a critique of computer graphics entirely. Manovich has written at length about experimental digital media. Instead, he is making a connection between the industries and institutions that develop new tools like physics simulations and the restrictive nature of the forms of representation they offer.

Harun Farocki mobilizes a similar sort of critique of simulation, media industries, and the military in his video series Parallel $I-I V$. In these works, he uses several examples of nonlinear animation, including animations of clouds, waves, and trees. Anselm Franke writes that these images in the Parallel series are shown to be a form of "representation (that) seeks to overcome lived reality by constructing, monitoring, and governing it." 16 Positioning progressively more technologically sophisticated and photorealistic images in sequence, his films suggest that the contemporary animation of clouds or trees in cinema and games is not the product of human invention or interpretation, but merely the product of functional technical ends. In this way, he sees these images as an extension of the operational or operative images he has theorizes elsewhere: images not meant to be interpreted or experienced by humans but instead meant to have a functional utility for machines or computation, like the computer vision of a guided missile. ${ }^{17}$ This operational vision subordinates reality to efforts to manage and control it.

Thomas Elsaesser's interpretation is that the Parallel films see simulated computer graphics as representing the "new invisibility" of contemporary life, referring not to materiality, the way tradition film does, but instead to the digital transactions, protocols, and ledgers that make up the reality of our contemporary lives. In this sense, the Parallel films construct simulated computer graphics as a form of "post-cinema," as theorized by scholars like Steven Shaviro. ${ }^{18}$ Yet, while the scholarly discourse of postcinema is generally oriented toward understanding the way digital media are relevant to our lived experience, Elsaesser's interpretation is that the Parallel films instead focus on the way simulated computer graphics alienate us from reality, the way they obfuscation and elide the "harsh materiality and deadly consequences of a world that now lives by the simulated image." 19 For Farocki, nonlinear animation is hyperrealism in the worst sense of the word.

This critique of nonlinear animation that interprets it as hyperrealism focuses on the way it promises reality but instead delivers a way of seeing 
that is in rationalizing, instrumentalizing, alienated from material reality, and deeply rooted in military and industry. This critique is not wrong. This book has offered a plethora of examples as to how R\&D complexes simultaneously supported nonlinear animation alongside military projects and management techniques focused on extracting more capital from workers. It has also shown how R\&D complexes have extending further into film industries and film production over time, displacing and replacing workers through automation and flexible workflows. Nonlinear animation is part of an evolving regime of control that often trades in a rhetoric of liberal freedoms, innovation, and creativity, but which also extends the ability of businesses and institutions to control systems, processes, markets, and workers.

Yet, like other forms of digital animation and like the multiplane camera before them, nonlinear animation does not only create a single type of moving image. Indeed, the way nonlinear animation involves building different mechanisms to drive motion makes it particularly open to alternate forms. As Chap. 4 showed, nonlinear animation incorporates engineering as a fundamental component of animation production. While this might make nonlinear animation seem more rationalizing and technical, this is not necessarily the case. As Chap. 2 argued, making a nonlinear animation requires adopting different assumptions about the mechanisms producing motion. Different assumptions imply different schema for seeing the world, and different apparatuses for producing motion. It is like technicians and artists are constantly reinventing the camera. The use of off-theshelf software minimizes this effect, and these animations will still be processed through other $3 \mathrm{D}$ animation schemata of representation like rendering, but the fact of engineering being a part of production means that the representational apparatus will always have a degree of flexibility. To fully appreciate the potential of this, we need to shift the way we think about media and knowledge away from "knowing that" and instead think in terms of the "knowing how" epistemology.

Theoretical discussions of the epistemology of cinema have only ever worked within the category of "knowing that." Cinema is sensory; it presents images and sounds of the world. We have neglected how media technicians represent the world through building apparatuses and experimenting with them - in other words, through "knowing how." Focusing on how nonlinear animation represents the world through "knowing how" requires us to take seriously the contributions of engineers and technical workers as a part of film production. Indeed, taking this approach not only 
elucidates the meaning of digital media from the past few decades, but also allows us to recognize practices in film production that have being going on for over a century. As a practice that entails special technical work, practical special effects offer particularly good examples of "knowing how."

Practical effects are profilmic effects, things like stunts and explosions. Early cinema is full of these types of effects, though they receive a fraction of the attention early visual effects like the "stop trick" receive. For example, in Edwin S. Porter's much discussed film for Edison The Great Train Robbery (1903) there is an explosion that sends fluttering currency notes and spectacular rings of undulating smoke into the air. Superficially, there is nothing cinematic about practical effects such as these. They were clearly used in magic shows and other forms of theatrical entertainment before cinema. But these bits of chaotic material movement are very cinematic. They have the same appeal as the natural motion found in contemporaneous actualities. Georges Sadoul describes early audiences as being most impressed by puffs of smoke or dust clouds in early films. ${ }^{20}$ There is no reason such motion in artificial circumstances should be any less compelling, and these are all examples of what physicists and mathematicians would now label nonlinear phenomena.

Practical effects put natural nonlinear motion from water, smoke, fire, wind, snow, or rain in artificial, controlled conditions. The practice that offers the clearest parallel to contemporary nonlinear animation is likely the water tank. Starting in the 1910s, Hollywood studios began to feature large water tanks as part of their set repertoires. Famous Players-Lasky first built a tank for a sinking of the Lusitania scene in Cecil B. DeMille's wartime feature The Little American (1917). Then, in 1922 United Artists built a tank for Maurice Tourneur's Isle of Lost Ships. Decades later, studios were still investing in bigger and better tanks, such as Toho's "big pool" (1960) and Fox's "Sersen Lake" (1962). Several large tanks from this era continue to be in use, including ones at Pinewood Studios, Cinecittà studios, and a large "horizon tank" on the seashore in Malta.

These tanks featured different hydraulic and mechanical devices for creating waves and large fans for creating wind, and they were designed to accommodate large sets that might simulate the sinking or listing of a ship. Sometimes they would be life sized, but of course there is also a long tradition of scale models and maquettes being used in water tanks. These are essentially fictionalized versions of contemporaneous wind tunnels and hydrodynamic water tanks that were becoming popular for engineering 
and R\&D. They recreate material conditions in miniature. They are simulations.

Such practical effects have themselves been criticized as a kind of hyperrealism. Siegfried Kracauer discusses artificial snowstorms in this capacity. Comparing German and Swedish film production cultures, he writes that if the Swedes wanted to record a scene with a snowstorm they would go outside, while the Germans, with their highly technical, industrial studio system, would opt to create a fake snowstorm in a giant indoor set. ${ }^{21}$ The implication here is that the German system is more artificial, less open to the contingency of reality. This is a trope that resonates strongly with realist strains in film theory. Yet we might consider the fake snowstorm as a simulation, not in the sense of being a mere artificial copy, but in the sense of modeling certain aspects of a process, like an aerodynamic model of an airplane in a wind tunnel. This is a way of understanding and representing reality through building apparatuses.

Nonlinear animation is thus part of a long tradition of technical workers making apparatuses to stage moments of material complexity and emergence, and this work represents a way of approaching materiality through "knowing how" rather than film and animation's traditional "knowing that." To say that these images are so artificial they make no reference to material reality, or that they "overcome lived reality by constructing, monitoring, and governing it," underestimates the complexity of meaning they are capable of having. Few forms of representation in culture are that easily dismissed. True, nonlinear animation is a product of military-turned-corporate $\mathrm{R} \& \mathrm{D}$, and it clearly plays an important economic role in contemporary VFX and animation industries. But it can tell us a great deal about the way society and culture are seeking to understand and represent our economic, organizational, and material world. Though examples like the nonlinear animation in The Day After Tomorrow or The Perfect Storm are risible, they have a lot to tell us about the way culture is negotiating new epistemological frames that are fundamental to understanding important issues like the future of climate change. We have been unpacking the complex meaning of photochemical film and cinematic conventions in the context of industrial modernity for decades. The tools and images produced by ranks of new technical media laborers in VFX, animation, and game studios warrant the same kind of scrutiny. 


\section{Notes}

1. Tom Gunning, "Animating the Nineteenth Century: Bringing Pictures to Life (or Life to Pictures?)," Nineteenth-Century Contexts 36, no. 5 (October 20, 2014): 459-72; Harkema, Gert Jan. "Move as if Alive: The Kinematograph as Unstable Technology of Movement and its Impact on the Spectator." Synoptique 5, no. 2 (Winter 2017) 1-14.

2. Raymond Williams, Television: Technology and Cultural Form (London: Fontana/Collins, 1974), 14.

3. Dudley Andrew, What Cinema Is! Bazin's Quest and Its Charge (Malden, MA: Wiley-Blackwell, 2010), 18.

4. Andrew Darley, "Second-Order Realism and Post-Modern Aesthetics in Computer Animation," in Animation Reader: A Reader in Animation Studies, ed. Jayne Pilling (Sydney: John Libbey, 1997), 16.

5. Sergei Eisenstein, "On Disney," in The Eisenstein Collection, ed. Richard Taylor (London; New York: Seagull Books, 2006).

6. Paul Wells, Understanding Animation (New York: Routledge, 1998), 21.

7. Norman Klein, "Animation and Animorphs," in Meta-Morphing: Visual Transformation and the Culture of Quick-Change, ed. Vivian Carol Sobchack (Minneapolis: University of Minnesota Press, 2000).

8. Wells, Understanding Animation, 24.

9. Pat Power, "Animated Expressions: Expressive Style in 3D Computer Graphic Narrative Animation," Animation 4, no. 2 (2009): 111.

10. Power, "Animated Expressions," 109.

11. Redrobe Beckman, "Introduction," 2.

12. Jean-Louis Baudry and Alan Williams, "Ideological Effects of the Basic Cinematographic Apparatus," Film Quarterly 28, no. 2 (1974): 39-47.

13. Lev Manovich, The Language of New Media (Cambridge, Mass.: MIT Press, 2002), 191-92.

14. Manovich, The Language of New Media, 191.

15. Manovich, The Language of New Media, 193.

16. Anselm Franke, "Harun Farocki - Exhibitions," PROA Foundation, 2012, http://www.proa.org/eng/exhibition-harun-farocki-obras-1.php

17. Harun Farocki, "Phantom Images," Public, no. 29 (2004): 17.

18. Steven Shaviro, Post-Cinematic Affect (Ropley: Zero, 2010).

19. Thomas Elsaesser, "Simulation and the Labour of Invisibility: Harun Farocki's Life Manuals," Animation 12, no. 3 (November 1, 2017): 226.

20. Dai Vaughan, For Documentary (University of California, 1999), 4.

21. Siegfried Kracauer, Theory of Film: The Redemption of Physical Reality (Princeton University Press, 1997), 74. 
Open Access This chapter is licensed under the terms of the Creative Commons Attribution 4.0 International License (http://creativecommons.org/licenses/ by $/ 4.0 /)$, which permits use, sharing, adaptation, distribution and reproduction in any medium or format, as long as you give appropriate credit to the original author(s) and the source, provide a link to the Creative Commons license and indicate if changes were made.

The images or other third party material in this chapter are included in the chapter's Creative Commons licence, unless indicated otherwise in a credit line to the material. If material is not included in the chapter's Creative Commons licence and your intended use is not permitted by statutory regulation or exceeds the permitted use, you will need to obtain permission directly from the copyright holder. 